\title{
THE LEARDERSHIP ROLE OF SCHOOL PRINCIPALS IN ONLINE LEARNING DURING THE COVID-19 PANDEMIC
}

\author{
Ainur Rahman', Subiyantoro² \\ Islamic Educational Management Department, Universitas Islam Negeri Sunan Kalijogo, \\ Yogyakarta, Indonesia \\ E-mail: hainurrahman94@gmail.com¹, subiyantorodr@gmail.com²
}

DOI: http://doi.org/10.33650/al-tanzim.v5i1.1805

\begin{tabular}{l|l|l} 
Received: January 2021 & Accepted: March 2021 & Published: March 2021
\end{tabular}

\begin{abstract}
:
This study aims to describe and analyze the leadership role of school principals in online learning during the Covid-19 pandemic. This study used a qualitative approach with phenomenology. The research site at SD Negeri Krapyak Wetan. The data collection technique is done through interviews, documentation and observation. Data analysis was carried out through data collection, data reduction and ending with drawing conclusions. The results showed that; the role of the principal's leadership in online learning during the Covid-19 pandemic, is; a) Optimizing learning and deliberations with teachers, b) Providing education and training on online learning platforms (online), c) Providing appreciation and motivation to teachers, students and guardians of students, d) Conducting multidirectional coordination and communication.
\end{abstract}

Keywords: Principal Leadership, Online Learning, Covid-19

\begin{abstract}
Abstrak:
Penelitian ini bertujuan untuk mendeksripsikan dan menganalisis tentang peran kepemimpinan kepala sekolah dalam pembelajaran daring di masa pandemi Covid19. Penelitian ini menggunakan pendekatan kualitatif jenis fenomenologi, dengan situs penelitian di SD Negeri Krapyak Wetan. Teknik pengumpulan datanya dilakukan melalui interview, dokumentasi dan observasi. Analisis datanya dilakukan melalui pengumpulan data, reduksi data dan diakhiri dengan penarikan kesimpulan. Hasil penelitian menunjukkan bahwa; peran kepemimpinan kepala sekolah dalam pebelajaran daring di masa pandemi Covid-19 yaitu; a) Melakukan optimalisasi pembelajaran dan musyawarah dengan para guru, b) Memberikan pendidikan dan pelatihan tentang platform pembelajaran daring (Online), c) Memberikan apresiasi dan motivasi kepada guru, peserta didik dan para wali murid, d) Melakukan koordinasi dan komunikasi multi arah.
\end{abstract}

Kata Kunci: Kepala Sekolah, Pembelajaran Online, Covid-19 


\section{INTRODUCTION}

The pandemic that has hit all regions of the world has had a significant impact on various kinds of life. Both developed countries and developing nations are also affected by the corona virus disease. Solomon (2020) said that the corona virus desease (Covid-19) is a new type of virus that hits the immunity of the human body that can bring about death. The Covid-19 pandemic attacks anyone at any age. One sector that has been affected is education (Mustajab \& Fawa'iedah, 2020). Education is very important, yet the existence of the Covid-19 is a challenging thing that must be faced together by the nation. The Covid-19 was detected entering Indonesia in February 2020, where at that time only few people were confirmed positive for Covid-19. Further the number of people infected has continued to increase from day to day, resulting in a real crisis (Sudika, 2020).

In the 2003 Law concerning the National Education System (SISDIKNAS) article 1 paragraph 1 it is explained that education is a conscious and planned effort to create an atmosphere of learning process so that students actively develop their potential to have religious spiritual strength, self-control, intelligence, personality, noble character, social competence and skills needed by him, the nation and the State. From several objectives contained in the law, it is explained that education is a process that must be carried out and a human right for every Indonesian citizen. Therefore in order to obtain proper education, citizens have the right to choose an educational institution, which is in line with their wishes and expectations (Hasanah, 2020).

The Ministry of Education and Culture of the Republic of Indonesia issued the Act Number 4 of 2020 concerning the implementation of educational policies in the emergency period of the spread of the corona virus (Ministry of Education and Culture, 2020), which reads as follows; a) Learning from home can be focused on life skills education, among others regarding the Covid-19 pandemic, b) Learning from home through distance or online learning is carried out to provide a meaningful learning experience for students, without making it a burden to complete all curriculum achievements for graduation or class promotion, c) Products or evidence of home learning activities are given qualitative and useful feedback by the teacher, without being required to provide a quantitative score, d) Tasks and learning activities from home can vary between students, according to their individual wishes and circumstances, including considering gaps in facilities or access to learning at home (Natural, 2020).

Djumiko et al., (2020) argues that during the Covid-19 pandemic, the spirit of sincerity and devotion from the principal is extremely needed in encouraging improvement from both stakeholders and the participation of school residents. The manifestation of a spirit of sincerity and devotion illustrates the presence of a sense of empathy for the crisis that is being faced by all people in the world. "Empathy is understood as an ability to understand the needs of others, which means to understand correctly other people's thoughts and feelings." 
Ats-Tsauri \& Munastiwi (2020) suggest, the strategies applied by the principal of madrasah in the implementation of learning in the era of the Covid19 are; 1) Applying student assessments online, so that it can be done as usual by teachers in schools, 2) Programming, compiling, determining and implementing learning during the Covid-19 pandemic which has a great opportunity to achieve a learning goal, 3) Adding programs that can be done directly at home, and 4) Providing an understanding of students and teachers regarding the online learning (distance learning). Hence, the principal of the madrasa adopts a learning policy that could be done online through platforms and social media during the Covid-19 pandemic. This research uses a qualitative approach.

Sudrajat et al., (2020) state that the principal's leadership strategy in improving the quality of kindergarten education during the Covid-19 is very good, namely 85.90 percent. The process approach, which is 88.24 percent, is the highest score, describing the approach to prioritizing things to be done. However, the responsibility is 81.21 percent in the form of a low score, which describes the implementation of the leadership of the school principal during the Covid-19 pandemic that is not optimal. This research uses a quantitative approach with a descriptive survey method.

Supriadi (2020) suggests that there is an unequal role orientation of the Early Childhood Education (PAUD) principal in the implementation of education before and after the Covid-19 occurs. The PAUD school principal plays a role as an educator before the pandemic, namely 84.58 percent to 73.38 percent during a pandemic, supervisor from 76.61 percent to 71.15 percent, leader from 71.19 percent to 68.01 percent, manager from 70.95 percent to 75.95 percent, while the role as an innovator 68.63 percent to 74.76 percent, motivator from 73.33 to 74.76 percent and administrator 72.38 percent to 78.33 percent. This research uses a quantitative approach with a survey method.

The principal has a strategic policy-determining role in an educational institution. The principal is the key driving force for the improvement and development of the school (Dakir, 2018). The principal of the madrasah is the leader in an organization. It is the principal who is responsible for enhancing student success and activities at school. In the era of Covid-19, schools have failed to determine mandatory policies with well-established considerations so that they can be maximally successful (Ats-Tsauri \& Munastiwi, 2020). The success of the leadership of the school institution depends on how the process of this ability is in positioning oneself as a teacher who educates, communicates, develops regular agility and the ability to make himself a good example; someone can be a motivator for his subordinates (Syadzili, 2019).

Those who can give assignments and orders to teachers are the principal to prepare a learning system that can facilitate students' learning through online learning. Teachers must be able to arrange learning that is in line with student needs and learning in the form of effective and competent abilities of students. During the Covid-19 pandemic, teachers can be creative and can take advantage of the technology system to keep learning and gain knowledge from the learning experiences prepared by the teachers (Arpius, 2020). 
Departing from the background presented, the researchers are interested in conducting a study as an effort to find out how the leadership role of school principals and teachers in designing learning implementation programs during the Covid-19 era through online learning. In this paper, we will describe the role of the principals in learning during the Covid-19 pandemic at the Krapyak Wetan Public Elementary School. The aim of the research is to be able to increase the leadership role of school principals and teachers in designing good and smooth learning activities during the Covid-19.

Primary school (SD) principals are the subject of discussion, considering that the functions and duties of primary school principals are not lighter than those of upper-level principals and higher education principals, because elementary school children are those who are still not independent. The previous studies use a quantitative approach, whereas this study employs a qualitative approach.

\section{RESEARCH METHODS}

This research examines the role of principal leadership in online learning at SD Negeri Krapyak Wetan Panggungharjo Sewon Bantul, Yogyakarta. The researchers were interested in writing and telling about the leadership role of the school principal during the Covid-19 in the location because either of them is one of the teaching staff there.

The method used in this writing is qualitative research methods with phenomenology. The qualitative method emphasizes the in-depth understanding of a problem (Sukardi, 2011).

Data sources received and processed in this study are from school principal informants and personal experiences in teaching during the Covid-19 pandemic at SD Negeri Krapyak Wetan. Data collection techniques used in this study are observation, interviews and other supporting data. Data analysis was carried out through data collection, data reduction and ending with drawing conclusions.

\section{DISCUSSION AND RESULTS Principal Leadership}

Leadership is defined by the word 'head' or 'leader'. Hasibuan argues about the leader and leadership as follows: 1) A leader (head) is someone who exercises authority and leadership, provides direction to his members or followers to do their work in order to achieve a common goal in organization, 2) A leader is the one who has a character of leadership and authority (Saleh \& Aini, 2014).

Leadership includes an influencing process in deciding an organizational goal, motivating adherent behavior to achieve a goal, influencing group and cultural changes (Hasanah, 2017). Leadership is in the form of art in leading someone's possession. With that art, the leader can manage in an orderly and effective manner (Nurmiyanti \& Candra, 2019).

As a leader, the principal is responsible for the achievement of an educational goal by ordering his subordinates towards achieving an educational goal that has been set (Julaiha, 2019). The ability to encourage and 
motivate others in order to realize the vision of the organization and being able to move his subordinates is one of the categories that must be owned by a leader (Purwanto, et al., 2020). Basically, leadership is an activity to influence and direct someone to achieve a vision, mission and goals that are planned together (Bashori, 2019).

The key to school success is basically the effectiveness and efficiency of the principal, because the success and smoothness of an educational institution is the success of the principal itself. One of the categories of school success requires quality leadership of the principal (Sumidjo, 1999). The leadership quality of the principal is needed, so it is always emphasized that the three strengths and abilities that the principal leadership need to have are conceptual skills, human skills and technical skills (Amini \& Ginting, 2020).

The success of an educational institution is very much dependent on the leadership of the principal. The principal is the leader of the institution, therefore the principal must guide the institution on the path to achieving the planned goals. The principal must be able to read changes and be able to read the future in the life of globalization and be able to realize productive, effective, efficient and fun learning activities. The principal must be responsible for the success of all activities and management, both formal and informal (Hasanah, 2020).

As a person who is fully responsible, the principal must be able to cooperate with other people in educational institutions, in this sense that he/she must be able to mobilize and coordinate the potential that exists in the institution. In this case the principal is fully authorized to carry out teaching and learning activities through other people, namely teachers. The teaching and learning activity needs to go well as planned even though in the Covid-19 era it is carried out online. This is where the leadership role of the principal is required to be able to improve and develop learning, manage good learning, coordinate, organize and implement regulations and policies that will be implemented in education institutions (Hasanah, 2020).

The leadership adopted by school principals during the current pandemic can use a situational leadership style, so that the educational process can continue to move by emphasizing the success of educational goals. Situational leadership that is able to match itself to the circumstances of the situation and conditions that are taking place should be understood that the success of the leadership is ensured by the behavior of the leader and organizational situational causes (Hazizah, 2020).

\section{Online Learning}

Online learning has a meaning that is not the same as learning. Learning is an activity to improve cognitive aspects that develops students' thinking power and manage new knowledge (Saifulloh \& Darwis, 2020).

In a decree circulated by KEMENDIKBUD No. 36962 / MPK_A / HK / 2020 concerning Online Learning and Working from Home in the Context of Preventing the Spread of Covid-19. All levels of education, from elementary school to college, during the Covid-19 pandemic, are required to carry out 
teaching and learning activities from home. Distance learning or online is an option for both the teacher and the students themselves.

Online learning is distance learning through established social media. Students and teachers can discuss subject matter with their group friends. The media used are Whatsapp group, google classroom, google meet, teams, dragon learn, zoom, etc. Online learning requires personal responsibility, independence and patience because someone can only himself. They must download and read materials, answer questions or quizzes and submit assignments independently. Online learning provides various learning media, such as videos connected to YouTube, video conference, scientific journal or digitally systemized topics (Amalia \& Fatonah, 2020).

Online learning can be used as a distance learning within a natural disaster that imposes social distancing regulations. Social distancing is enforced by the government in order to limit direct human interaction and avoid people from crowds so that there is no spread of Covid-19 (Syarifudin, 2020). Teaching and learning activities in the face-to-face context have been temporarily stopped by the existence of a policy from the government. Face-to-face learning is replaced with an online learning system by the government, using applications that support teaching and learning activities (Sudarsana et al., 2020).

The purpose of online learning is to provide quality learning assistance in a network that is open and accurate in order to reach a wider and more attractive place for learning. Online learning is a system that is implemented without face-to-face meetings, but uses a platform that can support a process of teaching and learning despite being online (Sofyana \& Rozaq, 2019).

\section{The Leadership Role of School Principals in Online Learning during the Covid-19 Pandemic}

The role is a cognitive process that is possessed by human beings in correcting information about the health of the residents of the environment through sight, hearing, feeling, appreciation and smell. The role is how humans perceive a thing depending on the location where the person acquire the behavior and conviction about the things to be faced (Noviardila, 2020).

The principal's role in the leadership of educational institutions in schools is to manage the school and his subordinates democratically and efficiently and cooperate institutionally, depending on the professionalism of their workers (Achmad, 2016). What determines the change in which direction the school wants is the responsibility and part of the key to the school principal (Susanti et al., 2020).

The leadership role of school principals in the current era of decentralization has become a necessity to carry out a meaningful action initiative in managing and leading the educational institutions that he leads. The strategic role of a school principal as an authority that he or she can improve and advance and direct the educational institution units that he manages to the path of success as stipulated in the 1945 Constitution is to educate the nation's life, which provides a contribution to the development of human resources of the nation and the State of Indonesia. In this case, the leadership of the principal must be truly innovative, instructive, creative and 
professional because so far, considering that the experience of the role of the principal is only instructive (top down), in today's era of industrialization 4.0 it is not sufficient for the sustainability of an educational institution. In this case the existence of life has depended on the role of information systems and technology, in that the results obtained from technological transformations are very fast and rapidly developing, which is a tangible manifestation of the development of information science and technology (Amini \& Ginting, 2020).

The leadership of school principals in Indonesia during the Covid-19 pandemic has rushed to make adjustments to address lesson planning. The process carried out by the principal is by deliberating with related parties at school, namely school leaders, guardians of students, teachers, foundations, regional heads and the education office (Indraswati \& Sutisna, 2020). In the first process, the school provides facilities and infrastructure that help learning by observing the HR (human resources) in evaluation materials, increasing creativity, the availability of facilities and infrastructure that help learning. The second process provides encouragement (motivation) to related parties (stakeholders) so that they work together to face Covid-19 with positive activities and focus on learning goals from related parties (stakeholders) to students (Asmuni, 2020).

The following is the leadership role of the principal in online learning for the Covid-19 pandemic at SD Negeri Krapyak Wetan Panggungharjo Sewon Bantul, Yogyakarta (Suyadi, 2020);

a. Optimizing All Elements of Education in Schools

The learning program that is in line with the current state of the Covid-19 is through optimization and utilization of existing technology. This process is necessary to consider the important things in online teaching and learning activities carried out by teachers and students. Online learning connects learners to their learning resources (experts / instructors, databases, bibliotics), in which although they are physically separated or distant, they can talk to each other, interact or collaborate either directly (synchronously) or indirectly (asynchronously). Online debriefing is a form of distance learning / training (PJJ) that uses telecommunications technology and informants, for example the internet (Smaldino, 2005).

The school principal and teachers made detailed and precise learning plans with regard to the distribution of lessons that would be carried out and discussed during the Covid-19 and asked each teacher of various subjects to be able to become partners and manage time up to the responsibility of students.

b. Carrying out Online Training

The principal is quite aware of the availability of facilities and capabilities of his/her school. All the teachers are less able to run the online platform and have the skills despite the availability of quota all the time. The role of teachers are aware of or understand Technology Science (IT) and receive international, national and local based trainings in the realm of Technology Science (IT). 
Teachers who understand Technology (IT) accompany other teachers who does not until the successful use and management of the platform can be done. Currently, regarding the quota of each teacher, the leader has put in the funds according to the circulation of the decree from the Minister of Education and Culture. The quota no longer becomes a barrier for teachers to actualize online teaching applications.

In SD Negeri Krapyak Wetan, 95\% of homeroom teachers and teachers can do IT; they use various online teaching applications such as: Google Classroom, Meet, Whatshapp, You Tube, Zoom and others.

c. Giving Appreciation and Enthusiasm for Teachers, Guardians and Students

Motivation for teachers is also conveyed by the principal, whatever the obstacles and problems it faces for teachers can be conveyed positively regarding the usefulness of social media (online) or the way it is desired to be obtained. Teachers teaching online means that they need extra energy to provide in terms of material, teaching time and others related to the online teaching system.

The principal always gives words of motivation, enthusiasm and also urges that in this era, students still have the enthusiasm to carry out activities given by the teachers to be done at home. Likewise, some guardians of students turned to feel unasy as they suddenly become facilitators of their children at home.

The school principal and teachers conveyed expressions of gratitude and words of appreciation to the parents of the students through WhatsApp group in several online classes. All parents or guardians provide very responsive feedback on assignments and others related to learning at school. The message of optimism and encouragement are sent to restore a sense of enthusiasm, which is in line with the perspective of education from Ki Hajar Dewantara: "Ing madya builds initiative" or in the middle of giving encouragement, this work is very good.

d. Carrying out Multi-directional Coordination of Sterilization Efforts in Education Units

The ongoing outbreak at this time has caused for concern of all related parties. Yet, the school is ready to play a role and involved in working to prevent the spread of the Covid-19.

The institution obtains assistance from the agency regarding the implementation of disinfectant spraying throughout the school institution in order to remain safe and useable for learning. 


\section{CONCLUSION}

The leadership of the principal holds a vital role as a leader in creating an educational atmosphere and ensuring that students still receive meaningful teaching. SD Negeri Krapyak Wetan actualizes distance learning or online learning for their students by collaborating with student parents as active controllers of how children develop at home. In online learning or distance learning the principal needs to also make learning protocols. The principal coordinates with stakeholders in order to deliver practical teaching materials.

The leadership role of the principal in online learning during the Covid19 pandemic at SD Negeri Krapyak Wetan is as follows: a) Optimizing and deliberating on teachers, b) Providing a short spirit of training on online learning platforms, c) Doing appreciation and giving motivational words of encouragement to teachers, students, and guardians of students, and d) Enforcing multi-way communication

\section{REFERENCES}

Achmad, A. K. (2016). Kepemimpinan Kepala Sekolah dalam Meningkatkan Mutu Pendidikan. J-MPI (Jurnal Manajemen Pendidikan Islam), 1(2), 115127.

Alami, Y. (2020). Media Pembelajaran Daring pada Masa Covid-19. Tarbiyatu Wa Ta'lim: Jurnal Pendidikan Agama Islam (JPAI), 2(1), 49-56.

Amalia, A., \& Fatonah, S. (2020). Penerapan Pembelajaran Daring Dragon Learn pada Era Pandemic Covid-19 (Studi Kasus di MI Ma'had Islam Kopeng). ISEJ: Indonesian Science Education Journal, 1(3), 148-164.

Arpius. (2020). Efforts To Improve Teachers Competence in Preparing Lesson Plan During The Covid-19 Pandemic Through in House Training. Jurnal Pendidikan dan Pengajaran (PAJAR), 4(6), 1259-1266.

Asmuni. (2020). Problematika Pembelajaran Daring di Masa Pandemi Covid-19 dan Solusi Pemecahannya. Jurnal Paedagogy, 7(4), 281-188. https://doi.org/10.33394/jp.v7i4.2941

Ats-Tsauri, M. S., \& Munastiwi, E. (2020). Strategi Kepala Madrasah dalam Menentukan Kebijakan Pembelajaran Era Covid 19: Studi Kasus Kepala Madrasah Ibtidaiyah NW Pondok Gedang. Elementeris: Jurnal Ilmiah Pendidikan Dasar Islam, 2(2), 56-61.

Bashori. (2019). Kepemimpinan Transformasional Kyai pada Lembaga Pendidikan Islam. Al-Tanzim: Jurnal Manajemen Pendidikan Islam, 3(2), 7384. https:// doi.org/10.33650/al-tanzim.v3i2.535

Dakir. (2018). Pengaruh Gaya Kepemimpinan Situasional Kepala Sekolah dalam Supervisi Akademik Terhadap Kompetensi Profesional dan Kinerja Guru. Yogyakarta: K-Media.

Djumiko, D., Fauzan, S., \& Jailani, M. (2020). Panduan Kepala Sekolah untuk Mengelola Sekolah pada Masa Pandemic Covid-19. Pedagogik: Jurnal Pendidikan, 15(2), 56-69. 
Hasanah, N. (2017). Kepemimpinan Kepala Sekolah dalam Pengembangan Lembaga Pendidikan. Al-Iltizam, 2(1), 24-50.

Hasanah, S. M. (2020). Kepemimpinan Kepala Sekolah dalam Meningkatkan Mutu Pembelajaran di Era Pandemi Covid 19. INCARE: International Journal of Educational Resources., 1(3), 257-279.

Hazizah, N. (2020). Leadership Headmaster in Improving The Quality of PAUD in The New Normal Period. SPEKTRUM: Jurnal Pendidikan Luar Sekolah (PLS), 8(2), 142-146. https:/ / doi.org/10.24036/spektrumpls.v8i2.109155

Indraswati, D., \& Sutisna, D. (2020). Implementasi Manajemen Mutu di SDN Prambon. Jurnal Dinamika Manajemen Pendidikan, 5(1), 10-21. https://doi.org/10.26740/jdmp.v5n1.p10-21

Julaiha, S. (2019). Konsep Kepemimpinan Kepala Sekolah. Tarbiyah Wa Ta'lim: Jurnal Penelitian Pendidikan \& Pembelajaran, 6(3), 51-62. https:/ / doi.org/10.21093/twt.v6i3.1734

Kemendikbud. (2020). Panduan Pembelajaran Jarak Jauh. Jakarta: Kementerian Pendidikan dan Kebudayaan.

Mustajab, M., \& Fawa'iedah, Z. (2020). Adapting to Teaching and Learning During Covid-19: A Case of Islamic School's Initiative of Self-regulated Learning. Nadwa, 14(2), 241-264.

Noviardila, I. (2020). Peran Kepala Sekolah dalam Proses Pembelajaran di Masa Pandemi Covid-19. Jurnal Bola (Bersama Olahraga Laju Asia), 3(1), 1-21.

Nurmiyanti, L., \& Candra, B. Y. (2019). Kepemimpinan Transformasional dalam Peningkatan Mutu Pendidikan Anak Usia Dini. Al-Tanzim: Jurnal Manajemen Pendidikan Islam, 3(2), 13-24. https://doi.org/10.33650/altanzim.v3i2.646

Purwanto, A., Sopa, A., Primahendra, R., Kusumaningsih, S. W., \& Pramono, R. (2020). Pengaruh Gaya Kepemimpinan Transactional, Transformational, Authentic dan Authoritarian terhadap Kinerja Guru Madrasah Tsanawiyah di Kudus. Al-Tanzim: Jurnal Manajemen Pendidikan Islam, 4(1), 70-80. https://doi.org/10.33650/al-tanzim.v4i1.938

Saifulloh, A. M., \& Darwis, M. (2020). Manajemen Pembelajaran dalam Meningkatkan Efektivitas Proses Belajar Mengajar di Masa Pandemi Covid-19. Jurnal Bidayatuna, 3(2), 285-311.

Saleh, K., \& Aini, A. N. (2014). Kepemimpinan Kepala Sekolah dalam Meningkatkan Kualitas Pendidikan (Studi Tentang Peran Kepala MTsN Model Samarinda dalam Meningkatkan Prestasi Kerja Guru). Jurnal Fenomena, 6(1), 19-37.

Smaldino, S. E. (2005). Instructional Technology and Media for Learning. Upper Saddle River: Prentice Hall.

Sofyana, L., \& Rozaq, A. (2019). Pembelajaran Daring Kombinasi Berbasis Whatsapp pada Kelas Karyawan Prodi Teknik Informatika Universitas PGRI Madiun. Jurnal Nasional Pendidikan Teknik Informatika, 8(1), 81-86.

Solomon, M. D., McNulty, E. J., Rana, J. S., Leong, T. K., Lee, C., Sung, S. H., \& Go, A. S. (2020). The Covid-19 Pandemic and The Incidence of Acute Myocardial Infarction. New England Journal of Medicine, 383(7), 691-693. 
Sudarsana, I. K., Lestari, N. G. A. M. Y., Wijaya, I. K. W. B., Krisdayanthi, A., Andayani, K. Y., Trisnadewi, K., \& Aryana, I. M. P. (2020). Covid-19: Perspektif Pendidikan. Medan: Yayasan Kita Menulis.

Sudika, I. W. (2020). Kepemimpinan Kepala Sekolah Dasar pada Era Revolusi Industri 4 . 0 dan Pandemi Covid 19. EDUKASI: Jurnal Pendidikan Dasar, 1(2), 113-124.

Sudrajat, C. J., Agustin, M., Kurniati, L., \& Karsa, D. (2020). Strategi Kepala TK dalam Meningkatkan Mutu Pendidikan pada Masa Pandemi Covid-19. Jurnal Obsesi: Jurnal Pendidikan Anak Usia Dini, 5(1), 508-520. https://doi.org/10.31004/obsesi.v5i1.582

Sukardi. (2011). Metodologi Peneletian Pendidikan: Kompetensi dan Prakteknya, Jakarta: Bumi Aksara.

Sumidjo, W. (1999). Kepemimpinan Kepala Sekolah. Jakarta: PT Raja Grafindo Persada.

Supriadi, O. (2020). Peranan Kepala PAUD dalam Penyelenggaraan Pendidikan Sebelum dan Saat Terjadi Pandemi Covid-19. Jurnal Obsesi: Jurnal Pendidikan Anak Usia Dini, 5(1), 841-856. https://doi.org/10.31004/obsesi.v5i1.727

Susanti, S., Lian, B., \& Puspita, Y. (2020). Implementasi Strategi Kepala Sekolah dalam Penguatan Pendidikan Karakter Peserta Didik. Jurnal Pendidikan Tambusai, 4(2), 1644-1657.

Syadzili, M. F. R. (2019). Polarisasi Tahapan Kepemimpinan Transformatif Pendidikan Islam. Al-Tanzim: Jurnal Manajemen Pendidikan Islam, 3(1), 5581. https://doi.org/10.33650/al-tanzim.v3i1.498

Syarifudin, A. S. (2020). Impelementasi Pembelajaran Daring untuk Meningkatkan Mutu Pendidikan sebagai Dampak Diterapkannya Sosial Distancing. Jurnal Pendidikan Bahasa dan Sastra Indonesia Metalingua, 5(1), 31-34. https://doi.org/10.21107/metalingua.v5i1.7072

Wah. (2020). Otonomi Pendidikan di Masa Kriris Pandemi Covid-19 (Analisis Peran Kepala Sekolah). Al-Muaddib: Jurnal Ilmu-Ilmu Sosial dan Keislaman, 5(2), 3-5-314. 